\title{
Kendala-Kendala BKB (Bina Keluarga Balita) Holistik Integratif di Provinsi Sulawesi Utara
}

\author{
Urip Tri Wijayanti \\ Peneliti Perwakilan BKKBN Provinsi Sulawesi Utara \\ haidar1602@yahoo.co.id
}

\begin{abstract}
The development of early childhood needs to be done holistik integrative. The service activities cover the aspects of care, health and nutrition. All Of whice can be obtained through posyandu; Aspects of education through early childhood (early childhood education) and aspects of parenting through Bina Keluarga Balita $(B K B)$ are carried out and applied in an integrated manner. Training and guidance for integrated integrative $B K B$ cadres has been done. The question is, after the cadres get training and coaching whether they can do integration between early childhood and Posyandu or there are obstacles that they face.For that need to be done research, this research is a qualitative research with $B K B$ cadres, PAUD cadres \& Posyandu cadres and families who become members of $B K B$. The results of this study concluded that the obstacles in the implementation Holistik integrative BKB include: (1). Lack of commitment among relevant sectors and partners, so there are not willing to provide integrative services with $B K B$. (2) Low quality data that is hindering the development of the group $B K B$ Integrative Holistik in the district / city(3). The low quality of cadres and PLKB, so an understanding of Integrative Holistik BKB still less so (4).The low awareness of parents to be active in the activities of $B K B$.
\end{abstract}

Keywords: communication barrier, family development, integrative holistik BKB

\begin{abstract}
Abstrak
Pengembangan anak usia dini perlu dilakukan secara holistik integrative Kegiatan pelayanan yang dilakukan mencakup aspek perawatan, kesehatan dan gizi. Kesemuaya itu bisa didapat melalui posyandu; aspek pendidikan melalui PAUD (pendidikan anak usia dini) dan aspek pengasuhan melalui Bina Keluarga Balita (BKB) yang dilakukan dan diterapkan secara terpadu. Pelatihan dan pembinaan bagi kader-kader BKB Holistik integratif sudah dilakukan,menjadi pertanyaan kita, setelah para kader mendapatkan pelatihan dan pembinaan apakah mereka sudah bisa melakukan integrasi antara PAUD dan Posyandu atau ada kendala-kendala yang mereka hadapi.Untuk itu perlu dilakukan penelitian, penelitian ini merupakan penelitian kualitatif dengan informan Kader BKB, Kader PAUD \& Kader Posyandu serta keluarga yang menjadi anggota BKB.Hasil penelitiannya antara lain (1).Rendahnya Komitmen antar sector terkait dan mitra kerja, sehingga masih ada yang belum mau memberikan pelayanan secara integrative dengan BKB. (2) Rendahnya Kualitas Data BKB sehingga menghambat pengembangan kelompok BKB Holistik Integratif di kabupaten/kota. (3). Rendahnya kualitas kader \& PLKB, sehingga pemahaman tentang BKB Holistik integratif masih kurang sekali (4). Rendahnya kesadaran orangtua untuk aktif dalam kegiatan BKB.
\end{abstract}

Kata Kunci: BKB Holistik Integratif, hambatan komunikasi, perkembangan keluarga 


\section{Pendahuluan}

Pembangunan keluarga merupakan suatu upaya mewujudkan keluarga berkualitas yang hidup dalam lingkungan sehat melalui pengembangan keluarga. Pembangunan keluarga merupakan tanggung jawab semua pihak termasuk BKKBN seperti diamanatkan dalam undang-undang nomor 52 tahun 2010 tentang Perkembangan Kependudukan dan Pembangunan Keluarga.Kebijakan pembangunan keluarga dilakukan melalui pembinaan ketahanan dan kesejahteraan keluarga. Salah satunya dilaksanakan melalui cara peningkatan kualitas anak dengan pemberian akses informasi, pendidikan, penyuluhan dan pelayanan tentang perawatan, pengasuhan dan perkembangan anak kepada keluarga yang memiliki balita.

Perlu diingat bahwa peningkatan kualitas sumber daya manusia (SDM) merupakan pilar utama pembangunan, karena kualitas SDM sangat menentukan kemajuan bangsa. Kualitas SDM antara lain dicerminkan oleh derajat kesehatan, tingkat intelegensia, kematangan emosional dan spiritual yang ditentukan oleh kualitas anak sejak janin dalam kandungan sampai anak usia 6 tahun. Dengan memperhatikan banyak faktor yang menentukan kualitas anak usia dini, maka pelayanan pengembangan anak usia dini perlu dilakukan secara holistik integrative, yaitu suatu bentuk pelayanan yang diwujudkan untuk memenuhi kebutuhan essensial anak secara utuh sesuai segmentasi umur anak mulai dari anak dalam kandungan sampai dengan usia 6 tahun.

Kegiatan pelayanan yang dilakukan mencakup aspek perawatan, kesehatan dan gizi melalui posyandu; aspek pendidikan melalui PAUD (pendidikan anak usia dini) dan aspek pengasuhan melalui Bina Keluarga Balita (BKB) yang dilakukan dan diterapkan secara terpadu. Keterpaduan ini harus dapat bersinergi dan berkelanjutan sehingga tujuan mengembangkan potensi anak secara optimal dapat tercapai.

Sulawesi Utara sendiri terdapat 4 kabupaten kota yang telah menerapkan BKB Terpadu. Ke empat kabupaten tersebut yakni,kota Manado, Bitung, kabupaten Minahasa Utaradan Minahasa.Selanjutnya pelatihan dan pembinaan bagi kader-kader BKB Holistik integratif di empat kabupaten/kota tersebut juga sudah dilakukan. Kemudian yang menjadi pertanyaan, setelah para kader mendapatkan pelatihan dan pembinaan apakah selanjutnya bisa di integrasikan dengan PAUD dan Posyandu sesuai dengan tujuan dari penyelenggaraan pengembangan anak usia dini holistik integratif atau ada kendala-kendala yang mereka hadapi. Maka dari itu pertanyaan penelitian ini adalahbagaimana gambaran BKB dan kendala-kendalaapa yang dihadapi dalam penerapan kelompok BKB terpadu di 4 kab/kota di Sulawesi Utara?

Tujuan dilakukan penelitian ini adalah untuk mengetahui gambaran kelompok BKB terpadu dan mengidentifikasi kendala-kendala dalam penerapan kelompok BKB terpadu di 4 (empat) kab/kota di Sulawesi Utara. Manfaat dari penelitian ini dapat menjadi bahan pertimbangan bagi pemerintah khususnya BKKBN baik Tingkat Pusat maupun tingkat Provinsi dan kabupaten/kota maupun stakeholder terkait, dalam hal Kelompok BKB Terpadu dan menjadi refensi bagi peneliti untuk penelitian selanjutnya. 
Pelayanan untuk anak usia dini holistik integratif dilakukan dalam rangka memenuhi kebutuhan esensial/dasar anak. Secara umum kebutuhan dasar anak meliputi kebutuhan fisik-biomedis (asuh), emosi/kasih sayang (asih) dan kebutuhan akan stimulasi mental (asah). Ketiga kebutuhan ini saling berkaitan, yang berarti bahwa seorang anak membutuhkan asuh, asih \& asah secara simultan, sinergis sesuai denngan perkembangan usia mereka.

Kebutuhan dasar pertama, kebutuhan fisik-biomedis meliputi: pemeliharaan pemenuhan kebutuhan gizi; perawatan kesehatan dasar seperti pemberian ASI, MP-ASI, menu seimbang, imunisasi, penimbangan teratur \& periodeik; bimbingan, agar anak mampu mengembangkan kemandirian sesuai dengan usianya; pendidikan, agar anak memperoleh kemampuan mengelola dasardasar sikap dan perilaku sesuai norma dan aturan; pembinaan, agar anak dapat mengembangkan potensinya,

Kebutuhan dasar berikutnya adalah emosi atau kasih sayang (asih), yang merupakan ikatan dan interaksi yang erat antara orangtua dan anak sejak janin dalam kandungannya dan terutama pada tahun-tahun pertama kehidupan anak untuk menjamin terwujudnya rasa aman. Kebutuhan dasar terakhir adalah pemberian stimulasi (asah) kepada anak, termasuk didalamnya proses pembelajaran, pendidikan dan pembinaan secara bertahap sesuai perkembangan usia anak, agar anak mampu mendayagunakan potensi dan kecerdasannya secara optimal, sehingga anak siap memasuki tahap perkembangan selanjutnya. (BKKBN : 2013)

Untuk penyelenggaraan pendidikan anak secara holistikintegratif mengacu pada 4 prinsip yaitu : (1) Pelayanan yang holistik artiya anak mendapat pelayanan kesehatan, gizi, perawatan; pendidikan dipusat pelayanan pendidikan, pengasuhan di rumah serta perlindungan dari perlakuan yang salah; (2) Pelayanan yang berkesinambungan artinya sistem pelayanan terkoordinasi dan terintegrasi serta memberikan pelayanan secara berkelanjutan sejak janin sampai usia 6 tahun; (3) Pelayanan yang tidak diskriminatif artinya pelayanan hendaknya memberikan perlakuan yang adil kepada seluruh anak baik laki-laki maupun perempuan; (4) Partisipasi masyarakat dimaksudkan agar masyarakat dilibatkan mulai dari tahap perencanaan, pelaksanaan, pemantauan dan evaluasi agar merasa memiliki sehingga program menjadi kuat. (BKKBN: 2013)

Pelayanan anak usia dini holistikintegratif sebagai suatu keterpaduan meliputi (1) Pelayanan untuk anakyang diberikan secara terus menerus dimulai dari janin sampai usia 6 tahun mencakup perawatan, pengasuhan, pendidikan dan perlindungan dengan tujuan agar anak dapat tumbuh dan berkembang secara optimal. (BKKBN:2011)Pelayanan untuk anak ini didapat dari Posyandu dan PAUD (2) Pelayanan untuk keluarga/orangtuayang diberikan untuk keluarga/orangtua dengan tujuan agar orangtua mempunyai keterampilan dalam mengasuh dan membina tumbuh kembang anak.Pelayanan dilakukan melalui kelompok Bina Keluarga Balita (BKB).

Salah satu hal yang bisa mendorong suksesnya pelayanan dalam kelompok Bina Keluarga Balita adalah faktor komunikasi.Sebab komunikasi menurut Redi Panjudu dalam Abdullah Masmuh merupakan sistem aliran yang menghubungkan 
dan membangkitkan kinerja antar bagian dalam organisais sehingga menghasilkan sinergi.(Masmuh, Abdullah: 2008)

Komunikasi memungkinkan orang untuk mengkoordinir kegiatan mereka untuk mencapai tujuan bersama.Begitupun dalam kegiatan BKB melalui komunikasi yang dilakukan oleh pengurus maupun antara anggota bisa mewujudkan tujuan dari dibentuknya BKB itu sendiri.Komunikasi yang disampaikan tentunya bisa berwujud lisan maupun tertulis.Komunikasi lisan banyak disukai oleh orang karena situasi keakraban yang ditimbulkan. Begitupun dalam kegiatan BKB dengan dibangunnya komunikasi lisan maka sesama anggota akan saling akrab dan memudahkan dalam menyampaikan tujuan dan pelayanan yang diberikan oleh kelompok BKB itu sendiri.

Dalam penyelenggaraan pelayanan terpadu antara 3 lembaga yang bertanggungjawab untuk melasanakan pelayanan sesuai dengan mekanisme operasionalnya. Mekanisme Operasional Pelayanan Anak Usia Dini Holistik Integratif seperti tabel dibawah ini :

Tabel 1.Mekanisme Operasional Pelayanan Anak Usia Dini Holistik Integratif

\begin{tabular}{|c|c|c|c|}
\hline Penyelenggaraan & POSYANDU & BKB & PAUD \\
\hline Waktu & 1 bulan sekali & $\begin{array}{l}1 \text { bulan sekali atau } \\
\text { dua kali }\end{array}$ & 3-5 kali seminggu \\
\hline Tempat & Di lokasi yg mudah d & jangkau masyarakat & $\begin{array}{l}\text { Lokasi mudah } \\
\text { dijangkau \& } \\
\text { menggunakan } \\
\text { sarana/bangunan yang } \\
\text { ada dalam syarat } \\
\text { (aman bagi anak) }\end{array}$ \\
\hline Fokus kegiatan & $\begin{array}{l}\text { Layanan Kesehatan } \\
\text { Ibu hamil, perbaikan } \\
\text { gizi \& peningkatan } \\
\text { kualitas bayi dan } \\
\text { balita }\end{array}$ & $\begin{array}{l}\text { Layanan kepada } \\
\text { keluarga tentang } \\
\text { pengasuhan \& } \\
\text { pembinaan tumbuh } \\
\text { kembang anak }\end{array}$ & $\begin{array}{l}\text { Layanan kepada anak } \\
\text { untuk } \\
\text { mengembangkan } \\
\text { seluruh potensi anak } \\
\text { melalui kegiatan } \\
\text { bermain }\end{array}$ \\
\hline Penyelenggara & $\begin{array}{l}\text { Kader posyandu } \\
\text { (Bimbingan dari } \\
\text { puskesmas) }\end{array}$ & $\begin{array}{l}\text { Kader BKB } \\
\text { (Bimbingan dari } \\
\text { PLKB) }\end{array}$ & $\begin{array}{l}\text { Kader PAUD } \\
\text { (Bimbingan dari } \\
\text { Pengelola Program } \\
\text { PAUD) }\end{array}$ \\
\hline
\end{tabular}

\section{Metode Penelitian}

Penelitian ini disusun berdasarkan pendekatan kualitatif dimana disajikan secara deskriptif realita masalah yang menjadi fokus penelitian dengan kata-kata tertulis atau lisan, sebagai gambaran tentang apa adanya suatu variabel, gejala atau fenomena yang dapat diamati berdasarkan latar alamiah orang atau individu. Dengan ciri penelitian kualitatif sebagai berikut (Nawawi:1995): memusatkan perhatian pada masalah yang ada saat penelitian dilakukan atau masalah-masalah actual, menggambarkan tentang masalah yang diselidiki sebagaimana adanya diiringi dengan interpretasi rasional yang cermat dan teliti. 
Urip Tri Wijayanti : Kendala-Kendala BKB (Bina Keluarga Balita) Holistik Integratif di Provinsi Sulawesi Utara

Penelitian ini dilakukan di lokasi kelompok Bina Keluarga Balita (BKB) Holistik Integratif di Provinsi Sulawesi Utara, dikembangkan di 4 kabupaten kota sebagai wilayah percontohan, sekaligus merupakan sasaran penelitian

1. Kota Manado : 37 kelompok BKB Holistik Integratif \& 185 anggota pengurus

2. Kota Tomohon : 35 kelompok BKB Holistik Integratif \& 175 anggota pengurus

3. Kota Bitung : 32 kelompok BKB Holistik Integratif \& 175 anggota pengurus

4. Kabupaten Minahasa Utara : 36 kelompok BKB Holistik Integratif \& 180 anggota pengurus

Fokus dalam penelitian ini adalah keterpaduan BKB dengan PAUD dan Posyandu yang ditinjau dari perkembangan kelompok BKB Holistik Integratif dan kendala-kendala pengembangan kelompok BKB Holistik Integratif.

Informan sebagai pemberi informasi ditentukan berdasarkan kriteriakriteria tertentu antara lain sebagai berikut:terlibat dalam kegiatan pengembangan BKB Holistik Integratif yaitu Kader BKB, Kader PAUD \& Kader Posyandu serta keluarga yang menjadi anggota BKB. Jumlah informan dalam penelitian ini berjumlah 8 orang meliputi Kader BKB sebanyak 4 orang, kader PAUD 2 orang, Kader posyandu 1 orang serta keluarga yang menjadi anggota $\mathrm{BKB}$ ada 1 orang

Teknik pengumpulan data yang digunakan dalam penelitian ini diperoleh lewat observasi dan wawancara para informan.Fungsi observasi dalam penelitian kualitatif yaitu mengamati langsung objek untuk mengetahuikeberadaan objek, situasi, kondisi, konteks, ruang beserta maknanya.Untuk memperkuat data observasi, peneliti juga akan melakukan wawancara untuk mensinkronkan jawaban informan dengan kenyataan yang terjadi. Melalui wawancara peneliti akan mengetahui hal-hal yang lebih mendalam tentang partisipan dalam menginterpretasikan situasi dan fenomena yang terjadi, dimana hal ini tidak bisa ditemukan melalui observasi.

Pendekatan yang digunakan yaitu dengan menggunakan lembaran berisi garis besar pokok, topik atau masalah yang dijadikan pegangan dalam pembicaraan. Peneliti akan menggunakan daftar pertanyaan yang lebih terinci, namun bersifat terbuka yang telah dipersiapkan lebih dahulu dan akan diajukan menurut urutan dan rumusan yang tercantum.

Analisa data berpedoman pada pandangan Miles dan Huberman (1992) bahwa analisis kualitatif tetap menggunakan kata-kata yang biasanya disusun dalam teks yang diperluaskan. Data yang berhasil dikumpulkan diolah dan dianalisis dengan tahapan-tahapan berikut:

1. Mengedit data

Pada tahap ini data yang sudah terkumpul baik melalui wawancara maupun pengamatan, langsung diadakan pengeditan. Pengeditan dilakukan pada akhir-akhir proses pengamatan dan wawancara.

2. Reduksi Data

Dilakukan setelah data dibaca dan diteliti kembali dengan cara membuat abstraksi. Abstraksi merupakan usaha membuat rangkuman inti penelitian 
3. Mengkategorikan dalam satuan-satuan

Pengkategorian ini berdasarkan sumber-sumber data, teristimewa data yang diperoleh dari hasil wawancara dan pengamatan.Selanjtnya data tersebut disusun dalam bentuk satuan-satuan yang menyangkut sumber, jenis informan, lokasi dan memilah-milah menjadi kategori tertentu atas dasar pemikiran, institusi dan pendapat berdasarkan focus penelitian kemudian diberikan kode untuk menjaga kerahasiaan informan.

4. Penafsiran data dilakukan sepanjang penelitian

Dimana setiap data yang terkumpul langsung dilakukan penafsiran. Kegiatan ini dilakukan setelah proses wawancara dan pengamatan diklasifikasikan untuk memperjelas data agar setiap data yang diperoleh dianggap bermakna.

5. Menguji keabsahan data

Hal ini dilakukan dengan cara membaca kembali dokumen-dokumen tertulis yang dikumpulkan kemudian dibandingkan dengan data yang diperoleh dari hasil wawancara dan pengamatan.

6. Penarikan kesimpulan

Diawali dengan memahami hubungan-hubungan diantara gejalagejala/konsep-konsep yang ada dengan tetap terfokus pada jawaban sebelumnya agar bisa menjawab tujuan penelitian.

\section{Hasil Penemuan Dan Diskusi}

\section{Gambaran Umum Kelompok BKB di 4 Kab/kota}

Kelompok Bina Keluarga Balita di Sulawesi Utara saat ini berdasarkan data laporan pengendalian lapangan (Dallap) BKKBN menggambarkan suatu kenaikkan yang signifikan dalam kaitannya dengan pembentukan kelompok.

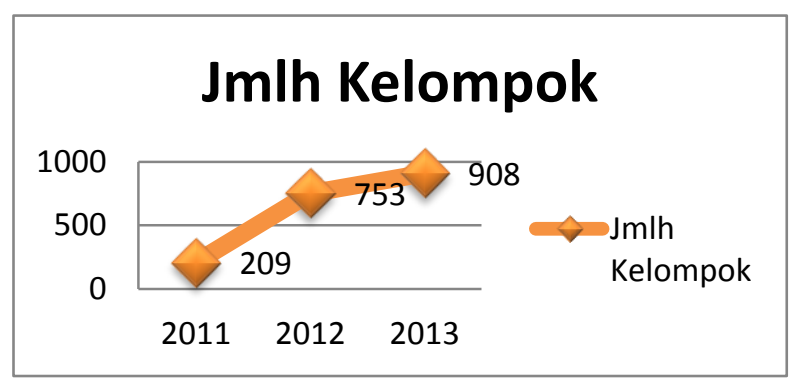

Gambar 1: Jumlah Kelompok Bina Keluarga Balita di Sumut (Sumber : Laporan Pengendalian Lapangan Perwakilan BKKBN Prov. Sulut)

Dari gambar diatas terlihat bahwa Pembentukan kelompok setiap tahun meningkat, diikuti oleh minat masyarakat untuk ikut berperan dalam kelompok Bina Ketahanan Keluarga balita baik sebagai anggota kelompok maupun menjadi kader. Untuk anggota kelompok sejak tahun 2011 sampai 2013 anggota kelompok BKB yang terdaftar berjumlah 25.015 keluarga, meningkat sebanyak 23.444 keluarga dari tahun 2011 yang hanya berjumlah 1.571 keluarga. Rata-rata anggota 
Urip Tri Wijayanti : Kendala-Kendala BKB (Bina Keluarga Balita) Holistik Integratif di Provinsi Sulawesi Utara

dalam setiap kelompok ada 28 keluarga.Sedangkan untuk kader BKB ada 2.533 kader yang dibina dikabupaten/kota \& dilatih di provinsi.

Untuk lebih jelas gambaran pertambahan jumlah anggota kelompok BKB, digambar dalam grafik berikut ini:

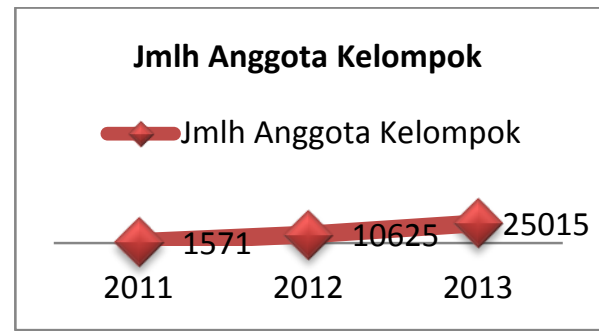

Gambar 2:Gambaran Pertambahan Jumlah Anggota Kelompok BKB

Dalam rangka penyelenggaraan pengembangan anak usia dini holistikintegratif maka dilakukan sutau pelayanan yang terintegrasi antara Posyandu (Kesehatan), PAUD (Pendidikan) \& BKB (BKKBN). Untuk Provinnsi Sulawesi Utara di terapkan di 4 kabupaten kota yang juga menjadi sasaran penelitian, yaitu Kota Manado, Kota Bitung, Kota Tomohon \& Kabupaten Minahasa Utara dengan jumlah kelompok sebagai berikut

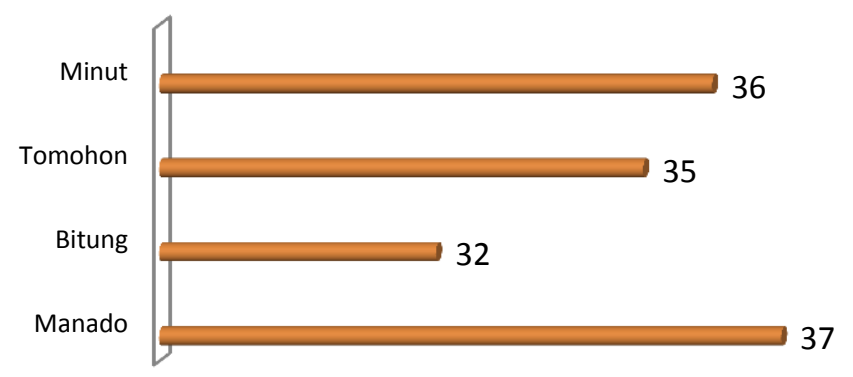

Gambar 3:Pelayanan Integrasi di 4 Kabupaten Kota

\section{SDM}

a. Petugas Lapangan KB

Petugas lapangan $\mathrm{KB}$ sebagai ujung tombak pelayanan $\mathrm{KB}$, diharapkan memiliki pengetahuan \& ketrampilan guna menyampaikan semua program Kependudukan dan KB. Termasuk didalamnya program Bina Ketahanan Keluarga Balita Holistik Integratif. Tetapi kondisi dilapangan menunjukkan bahwa ada petugas lapangan $\mathrm{KB}$ yang tidak memahami tentang program Bina Ketahanan Keluarga Balita Holistik Integratif. Bahkan ada petugas lapangan KB yang mungkin jarang sekali berkunjung kedaerah binaanya. Ketika peneliti turun di salah satu kecamatan di kabupaten Minahasa Utara, sekretaris desa ketika ditanya menyampaikan demikian

"Maaf, kader KB itu apa? yang saya tahu disini hanya ada kader posyandu. PLKB itu apa ?saya bahkan tidak mengenalnya sama sekali. Kalau untuk kelompok BKB, mungkin disini tidak ada.yang saya tau disini hanya ada PAUD saja. Yang menjadi kader paud adalah guru-guru atau bunda-bunda. Saya tidak pernah mendengar ada pertemuan orangtua dengan kader BKB di PAUD" 
Ketika dikonfirmasi via telepon ke salah satu guru/bunda di PAUD tersebut, dia menjelaskan

"memang BKB disini belum berjalan bagus. Pertemuan hanya dilaksanakan ketika ada posyandu baru diberikan materi BKB.BKB disini juga baru dibentuk sekitar bulan mei, jadi kami belum bisa maksimal untuk melaksanakan sosialisasi kepada anggota kelompok BKB yang terdaftar di PAUD. Untuk pertemuan hanya $2 x$ seminggu, itupun orangtua jarang sekali datang \& petugas lapangan belum melakukan pembinaan sampai saat ini"

Kondisi diatas jelas menggambarkan bahwa ada petugas lapangan yang tidak serius melakukan tugas tanggungjawabnya sebagai penyuluh lapangan KB. Dengan kondisi seperti ini sangat susah untuk menerapkan konsep BKB Holistik Integratif jika petugas lapangannya tidak konsen dalam melakukan advokasi \& KIE program KKB dilapangan.

Sesuai dengan strategi BKB Holistik Integratif, maka perlu adanya peningkatan komitmen, koordinasi dan kerjasama antar instansi pemerintah, lembaga penyelenggara layanan dan organisasi terkait.Hal inilah yang perlu dipahami \& diterapkan oleh petugas lapangan KB dalam kaitannya mengembangkan BKB Holistik Integratif diwilayah binaannya.

\section{b. Kader}

Kader sebagai pelaksana kegiatan perlu dibekali dengan pengetahuan, pemahaman tentang bagaimana mengembangkan potensi anak secara optimal khususnya kepada orangtua yang menjadi sasaran dari kegiatan Bina Keluarga Balita.Kader harus memahami seperti apa mekanisme operasionalnya, teknik penyampaikan materi khususnya kepada orangtua yang menjadi anggota kelompok BKB \& bekerja sama dengan kader PAUD serta Posyandu.

Kondisi dilapangan menunjukkan bahwa hal diatas masih jauh dari yang diharapkan.masih ada kader yang belum memahami betul apa saja materi yang disampaikan serta beberapa fungsi sarana prasarana BKB. Seperti yang disampaikan dalam wawancara

"saya sebagai bunda PAUD, kalau BKB saya lupa kepanjangannya (setelah dijelaskan baru dia mengerti, apa kepanjangan $\mathrm{BKB}$ ). untuk pemberian materi kepada orangtua, itu kami lakukan kalau pas ada pertemuan orangtua seperti penerimaan hasil ulangan. Kalau untuk fasilitas seperti alat permainan, buku-buku untuk orangtua anak, serta lembar balik dan lain-lain kami punya semua yang diberikan oleh $B K K B N$ sampai kantong wasiat tetapi kantong wasiat ini saya kurangtau penggunaannya.

Ada juga yang menyampaikan demikian

"saya PPKBD sekaligus kader BKB. Memang kami sudah mengikuti pelatihan BKB Holistik yang dilakukan BKKBN Provinsi ketika datang di Tomohon. Tetapi materi yang kami sampaikan sama seperti yang dibuku (Ketika ditanya salah satu materi)

Selain minimnya pengetahuan kader, juga minimnya jumlah kader yang ada.hal ini mengakibatkan banyak kader yang bekerja rangkap sebagai kader BKB, PAUD maupun posyandu. Hal ini mengakibatkan kurang maksimalnya kerja yang dilakukan oleh kader. 
Urip Tri Wijayanti : Kendala-Kendala BKB (Bina Keluarga Balita) Holistik Integratif di Provinsi Sulawesi Utara

\section{c. Orangtua/ anggota kelompok BKB}

Keseluruhan semua wawancara menunjukkan bahwa rendahnya minat orangtua untuk mendapatkan informasi dari kelompok BKB, mereka lebih tertarik mendengarkan materi dari posyandu atau konsul dengan dokter daripada kader.

Disini PAUD \& BKB sudah jalan... tetapi yang jadi masalah disini kwa itu orangtua yang kebanyakan dorang belum paham apa itu BKB, tapi kalo pas ada kegiatan posyandu yang torang jaga bekeng 1 bulan 1 kali dorang takumpul banyak, disitu no torang jaga kase sosialisasi tentang ini BKB. Kong dorang kwa suka skali kalo jaga konsul dengan dokter dorang nimau kalo Cuma bidan.

Pertemuan yang mereka lakukan hanya sebulan sekali, hal itu sesuai dengan penelitian Prihyugiarto dan Mario Ekoriano (2011) mengungkapkan pada umumnya pertemuan BKB dilakukan sebulan sekali, namun masih ada 15 provinsi yang mempunyai rasio pertemuan kurang dari satu kali, bahkan misalnya provinsi Sulawesi Tengah dan Maluku rata-rata pertemuannya masing-masing 0,31 dan 0,43 kali. Dengan kata lain bahwa di provinsi masih dijumpai adanya kelompok BKB yang tidak melaksanakan pertemuan bulanan.

\section{Analisis dan pembahasan}

Program bina keluarga balita (BKB) sebagai salah satu pelayanan anak usia dini yang bertujuan meningkatkan pengetahuan \& ketrampilan orangtua dalam pengasuhan dan pembinaan tumbuh kembang anak, harus diintegrasikan dengan program layanan anak usia dini yang lain, agar anak mendapatkan pelayanan secara utuh. (BKKBN: 2012). Sehingga dari konsep integrasi ini, kebutuhan essensi anak bisa terpenuhi \& generasi masa depan yang bermutu bukan lagi suatu hayalan tetapi menjadi kenyataan.

Seperti yang diuraikan dalam rangkuman hasil wawancara, banyak masalah yang muncul dilapangan berkaitan degan penerapan BKB Holistik Integratif.Berikut akan dijelaskan mengenai masalah yang dihadapi oleh Sulawesi Utara untuk 4 kabupaten kota yang menjadi percontohan awal secara.

Masalah pertama terletak pada rendahnya komitmen antar sektor terkait dan mitra kerja.Gambaran secara umum yang didapat dilapangan \& berdasarkan hasil wawancara menunjukkan bahwa pembentukan kelompok BKB Holistik integratif tidak berjalan sebagaimana mekanisme yang diharapkan. Ada instansi yang tidak mau terintegrasi karena merasa akan terjadi pengambilan hak. Sosialisasi, advokasi \& KIE merupakan suatu penguatan dari kegiatan yang dilaksanakan \& menarik dukungan dari luar. Kondisi seperti diatas menggambarkan bahwa kurangnya sosialisasi, advokasi \& KIE terhadap mitra kerja maupun stakeholder.Kunci daripada pemberian sosialisasi adalah bagaimana teknik mengkomunikasikan pesan yang kita sampaikan. Peneliti mengambil definisi komunikasi berdasarkan pendapat dari Harold D. Lasswell :1960) bahwa komunikasi pada hakekatnya adalah seperti suatu pertanyaan "Siapa mengatakan apa dengan saluran apa, kepada siapa dengan efek yang bagaimana?"

Penyampaian sosialisasi, advokasi \& KIE bukan hanya sekedar menyampaikan tetapi bagaimana informasi yang disampaikan memberi pengaruh terhadap mitra kerja atau stakeholder maupun masyarakat, sehingga ada feedback terhadap pesan yang disampaikan. Secara umum, informan menegaskan bahwa 
kelompok mereka terbentuk setelah mengikuti sosialisasi tetapi tidak mengerti apa yang akan dilakukan selanjutnya, sehingga karena mengalami kebingungan akhirnya mereka lebih fokus kepada kegiatan awalnya. Kesan yang muncul adalah pembentukan yang tergesa-gesa untuk memenuhi target capaian tanpa melihat efeknya.

Metode penyampaian informasi yang keliru akan mengaburkan pesan dan membentuk komitmen semu. Oleh sebab itu, peneliti membuat suatu pola komunikasi yang dikembangkan dari model Laswells dan mungkin bisa diterapkan untuk meningkatkan komitmen dalam pengelolaan BKB Holistik Integratif. Dalam model komunikasi ini, yang menyampaikan pesan atau yang akan memberikan sosialisasi harus betul betul-betul memahami tentang program serta tujuannya. Setelah itu bangun komitmen sendiri, karena sebelum membangun komitmen oranglain harus punya dulu komitmen sendiri berdasarkan program \& tujuannya. Ketika sudah terbentuk pemahaman \& komitmen maka individu sudah memiliki kompetensi untuk menyampaikan pesan dengan isi \& metode media yang akan digunakan sesuai dengan tujuan program \& kondisi penerima pesan. Masukan informasi serta sosialisasi akan menjadi penguatan persepsi penerima pesan, stake holder ataupun mitra kerja akan lebih mudah memahami apa yang sampaikan ketika disesuaikan dengan kondisinya. Tidak ada unsur pemaksaan tetapi unsur partisipatif $\&$ antisipatif yang dibangun. sebenarnya personal selling dapat digunakan dalam konteks ini. ibarat sebuah produk BKB holistic integrative adalah produk BKKBN sehingga pemasaran produk ini bisa dengan strategi personal selling. Pada intinya bertujuan untuk memperkenalkan sebuah produk / BKB agar mereka tahu akan keberadaaan produknya (Suherman Kusniadji, 2017)

Masalah kedua yang dihadapi adalah rendahnya kualitas data BKB.Data \& informasi yang akurat akan sangat mendukung keberhasilan suatu program atau kegiatan. Data adalah catatan atas kumpulan fakta atas sesuatu yang apa adanya.Data yang akurat sangat diperlukan untuk membangun suatu informasi bagi kelangsungan program, karena dari data yang ada akan tergambar bagaimana keberhasilan atau kegagalan selain itu analisis data juga sangat penting bagi pencapaian program dan membantu dalam menentukan kebijakan dan strategi yang tepat bagi pengembangan kelompok BKB disuatu wilayah. Data dilapangan menunjukkan ada data yang tidak sesuai dengan kondisi lapangan sehingga tergambar bahwa data dibuat hanya untuk memenuhi target/sasaran padahal data merupakan gambaran nyata dari suatu kegiatan.

Masalah ketiga adalah kualitas kader \& PLKB yang masih perlu ditingkatkan.Secara kuantitas kader \& PLKB masih kurang dilapangan, tetapi selain itu juga kualitasnya juga masih sangat rendah. Sehingga secara umum dari hasil wawancara menunjukkan bahwa mereka belum memahami betul tentang apa itu BKB. Untuk meningkatkan kualitas kelompok BKB diperlukan tenaga pengelola, pelaksana dan kader yang memahami hakekat, tujuan program serta keunggulan programnya atau dengan kata lain keberhasilan kelompok BKB harus ditunjang dengan kompetensi pengelola, pelaksana dan kader. Pengelola maupun Pembina kelompok BKB harus memiliki kompetensi, bagaimana menerapkan 
pengetahuan dan ketrampilan yang didapat melalui pelatihan maupun sosialisasi dalam lingkungan kerja khususnya kelompok bina.

Masalah berikutnya atau keempat adalah rendahnya kesadaran orangtua sebagai anggota kelompok BKB untuk aktif dalam kegiatan kelompok.Kewajiban \& tanggung jawab orangtua adalah untuk mengasuh, memelihara, mendidik dan melindungi anak serta menumbuh-kembangkan anak sesuai dengan kemampuan, bakat dan minatnya.Kelompok BKB bertujuan agar mempunyai ketrampilan dalam mengasuh dan membina tumbuh kembang anak, melalui penyuluhan \& pelatihan.Kondisi dilapangan pada umumnya menggambarkan bahwa rendahnya kesadaran \& minat orangtua untuk mendengarkan penyampaian dari kader BKB. Padahal pelanyanan anak usia dini holistikintegratif pada hakekatnya ditujukan agar kebutuhan essensi anak dapat dipenuhi secara utuh, juga orangtua memiliki pengetahuan tentang bagaimana memenuhi kebutuhan essensi anak tersebut.

\section{Simpulan}

Kesimpulan yang dapat diperoleh melalui penelitian ini adalah pertama BKB holistik integratif yang berada di empat kab/kota pada kenyataannya belum semuanya mampu berintegrasi, ada dua BKB yang mampu melakukan integrasi.Kemudian kedua, masih adanya kendala yang dihadapi dalam pelaksanaan pelayanan BKB holistik Integratif. Kendala-kendala tersebut antara lain: rendahnya Komitmen antar sector terkait dan mitra kerja, sehingga masih ada yang belum mau memberikan pelayanan secara integratif dengan $\mathrm{BKB}$; rendahnya kualitas data BKB sehingga menghambat pengembangan kelompok BKB Holistik Integratif di kabupaten/kota; rendahnya kualitas kader \& PLKB, sehingga pemahaman tentang BKB Holistik integratif masih kurang sekali; rendahnya kesadaran orangtua untuk aktif dalam kegiatan BKB.

Berdasarkan simpulan diatas, maka saran yang tepat adalah: (1) Perlu adanya pelayanan terintegrasi dengan dua lokasi tetapi ada satu waktu berada dalam satu lokasi; (2) Melibatkan PKK dalam Pengembangan Model BKB Holistik Integratif karena banyak program PKK adalah program KB, selain itu juga banyak ibu-ibu anggota BKB aktif dalam PKK; (3) Perlu dilakukan pengkajian kembali teknik sosialisasi bagi kader, PLKB dan Mitra kerja/Stakeholder.

\section{Ucapan Terima Kasih}

Penulis mengucapkan terima kasih kepada Kepala Perwakilan BKKBN Provinsi Sulawesi Utara Drs. Temazaro Zega, M.Kes yang memberikan kesempatan kepada penulis untuk menggunakan data hasil penelitian. Ucapan terima kasih pula untuk widyaiswara Perwakilan BKKBN provinsi Sulawesi Utara Deybie Y. Berdame, S.Psi, M.Si dan widyaiswara Balai Diklat KKB Banyumas Djamiul Ma'aruf, S.Sos atas berbagi pengalaman dalam penelitian. 


\section{Daftar Pustaka}

Badan Kependudukan dan Keluarga Berencana Nasional.(2011). Pegangan Kader Tentang Pembinaan Anak Balita. Jakarta: BKKBN.

Badan Kependudukan dan Keluarga Berencana Nasional.(2011). Pengasuhan anak Usia Dini Holistik Integratif 0-6 tahun.Jakarta : BKKBN.

Direktorat Balita dan Anak.(2012).Grand Design Pembinaan Ketahanan Keluarga Balita dan Anak.Jakarta : BKKBN.

Direktorat Balita dan Anak.(2012). Petunjuk Teknis Penyelenggaraan Pengembangan Anak Usia Dini Holistik Integratif Melalui BKB. Jakarta: BKKBN.

Badan Kependudukan dan Keluarga Berencana Nasional. (2013). Panduan Pelaksanaan Kegiatan Bina Keluarga Balita (BKB) yang Terintegrasi dalam Rangka Penyelenggaraan Pengembangan Anak Usia Dini Holistik Integratif. Jakarta : BKKBN

Masmuh, Abdullah.(2008). Komunikasi Organisasi dalam Perspektif Teori dan Praktek. Jawa Timur: Universitas Muhamadiyah Malang.

Nawawi.(1995).Metodologi Penelitian Bidang Sosial.Yogyakarta : Gadjah Mada University Pres.

Lasswell.(1960). The Structure and Function of Communication in Society. The Communication of Ideas. New York: Institute for Religious and Social Studies.

Miles, B. Mathew., \&Huberman, Michael.(1992). Analisis Data Kualitatif Buku Sumber Tentang Metode-metode Baru. Jakarta: UIP.

Prihyugiarto, Mario Ekoriano.(2011). Evaluasi Hasil Pelaksanaan Pencatatan danPelaporan Pelkon serta Kelompok BKB, BKR dan BKL.Jakarta : BKKBN.

Kusniadji, Suherman. (2017). Kontribusi Penggunaan Personal Selling Dalam Kegiatan Komunikasi Pemasaran Pada Era Pemasaran Masa Kini. Jurnal Komunikasi,Vol. 9, No. 2, 176-183. Retrieved from: 